THURSDAY, DECEMBER 7, I8\%

\section{THE CHAIRS OF SCIENCE IN THE SCOTTISH UNIVERSITIES}

$7 \mathrm{HE}$ biographer of a Scottish Professor says (we fear boastfully) that his friend had lectured on anatomy, chemistry, physiology, pathology, medical jurisprudence, and medicine, and that he was well qualified also to lecture on botany, mineralogy, and geology. There were giants then surely, but their day is past; for the Professor of Natural History in Glasgow University is just now trying to procure the erection of a new Chair, on the ground that geology or comparative anatomy is, either of them, as much as he can effectively teach. Perhaps no better indication of the enormous progress of Science during the last half century could be found than the facts we have mentioned. The earlier professor found his multifarious duties possible because the subjects were very limited, and, in physiology, chemistry, mineralogy, and geology, the means of investigation were few. Now geology has outgrown the dimensions of anatomy, as a teaching subject. The Chairs of Natural History in Scotland, now only two in number, those in Glasgow and Aberdeen (for Science is only provided for temporarily in St. Andrews at present at the cost of Civil History), are remarkable foundations. There is no clear notion what the Professors may not teach. Custom has settled that geology and zoology shall be expected of them, and the Ordinances of the University Commissioners act upon this tradition. But it is doubtful if successful restraint could be put upon an eccentric Professor who selected ethnology and meteorology as his topics. He would lose class fees; but as he holds from the Crown, and the Crown has not defined his duties, he would be legally safe. Fortunately there has been no attempt hitherto to act independently of University needs; on the contrary, there have been from time to time voluntary modifications of the class work, both as regards the length of the courses and the subjects, so as to meet the needs of students. But this very complaisance has been injurious; for, to take the case of Glasgow, the Universities (Scotiand) Act made zoology a compulsory subject for medical students, and the Court and Senate at a later date resolved to grant a degree in Engineering Science (modestly calling it a certificate), requiring geology as one of the subjects of examination. Complete systematic courses were therefore indispensable, and the attempt to provide these has demonstrated their impossibility; hence the present attempt to procure a change.

While sympathising with the Glasgow Professor, and with his colleagues in Aberdeen and in Queen's College, Ireland, we decline to discuss the question as one of individual hardship, or even as detracting from the efficiency of one or several Universities. The existence of lectureships which profess to be scientific, but which can only be popular if the work is equally divided between the different subjects, is an evil which demands a remedy, and Scotiand cannot be indulged in her fancy for multiple Chairs, as anatomy and botany, logic and rhetoric, moral philosophy and political economy, civil and Scots law. If the teacher has a strong yOL, v. bias in favour of either subject he will throw himself into that and neglect the other, even though it forms part of that curriculum for which a degree is granted. Now, apart from the degradation of a scientific honour, the lowering of the standard of scientific teaching is especially to be guarded against at the present time. There are too few inducements for young men to devote themselves to Science as a life profession, still less encouragement do they receive to devote their energies to one branch exclusively. If our Universities continue to sanction average teaching, it will be a substantial injury to education throughout the country, and will put an end to that scientific work upon which the progress of science and the reputation of the country ought to rest : for it cannot be expected that a man whose ideas are frittered away by desultory work can have either the inclination or the time for patient continuous research. It is to be regretted that the Scottish Universities are too poor to help themselves in this matter. Private liberality has placed Edinburgh in a.right position; geology and zoology being respectively the entire occupation of Geikie and Wyville Thomson. In Newcastle the new college has started wisely with one subject, geology; but it is to be hoped that zoology will ere long be added as a separate professorship. In the London colleges separate provision, such as it is, is made for these two branches of Science, and even in the Universities which flippant so-called Radicals are wont to denounce as effete, and to contrast unfavourably with their Scottish sisters, there is provision for teaching as well as for the teacher.

It is in the interest of these and other bodies that we urge the necessity of reforming Scottish Universities in the matter of Science teaching. If they are permitted to continue as at present, the good done by their better equipped rivals will be diminished. It is a mistake to suppose that one college is better off if the teaching in another is defective; that may happen for a year or two, but in the end all suffer for the fault of one, all are lowered in tone though they may not be brought equally low. To maintain English teaching, Scottish teaching must be raised. But as no funds exist on which a just claim may be established for this purpose, private generosity or the State purse are the only appeals. Cabinet Ministers have been known to talk of Science as having condemned itself if it is not self-supporting, and in London there is a current opinion that Science is too largely subsidised, comparatively speaking, north of the Tweed. But it must be remembered that in Glasgow and Aberdeen, even in Edinburgh, it is impossible, save in the exceptional case of the director of the Scottish Survey, to find a man qualified for the post, and at the same time deriving an adequate income from other sources; for the time is past when Science was the pursuit only of the wealthy. It may not be sound in principle, but it is a practical necessity for the State to endow Science in the provinces; failing that and failing local effort, it would be best, in the interests of sound education, to suppress the starved chair altogether. But in the particular cases at present under consideration there is a strong claim on the State; the chairs of Natural History are creations of the Crown, and as circumstances have altered greatly since their creation, it behoves the Crown to secure that its intentions are fulfilled by making corresponding alterations. 
Of course this is the final resort after it is clear that Scotsmen decline to supply the money needed; but in Glasgow at least it is not to be believed that the examples of Manchester, Birmingham, and Durham will be without effect. All that has been said is equally true of Ireland; but the practical treatment of the difficulty involves other considerations upon which we cannot at present enter.

\section{FUKES'S LETTERS}

Letters and Extracts from the Addresses and Occasional Writings of 7. Beete Fukes, M.A., F.R.S., F.G.S. Edited, with connecting Memorial Notes, by his Sister, with a Portrait. (London: Chapman and Hall, r871.)

T OW few among us-when his glass is run-would care 1 to have the story of his life from year to year, even from his boyish days, writ down and published to the world-indeed, how very few would be found worthy of more record than "born, lived, died." Now and again, however, one meets with a man whose career in life is not only lifted above the monotonous hum-drum existence of ordinary mortals, but who, both by his life and writings, attracts our admiration and regard.

Such a man was Joseph Beete Jukes, a sketch of whose life and writings, together with some two hundred letters, edited by his sister, Mirs. A. H. Browne, form the substance of this volume.

Blest not only with a goodly person and stature but with a noble and generous nature, which won to his side both the ignorant and the educated, Mr. Jukes was also a man of high mental endowments, and both as a speaker and a writer had the knack to command attention. But in his leisure hours no one entered more keenly than he into all the enjoyments of the country, being fond of hard riding, and a keen sportsman and good shot. Nor was he less fond of a good joke, as his letters often testify.

Educated at Cambridge during Sedgwick's palmy days,* no wonder that he caught some of the fre from "Old Adam," as his students lovingly nicknamed him, and instead of entering the Church, as his mother fondly hoped, inaugurated a career for himself by walling through Derbyshire, Staffordshire, Cheshire, Shropshire, Yorkshire, and many other parts of England, geologising and lecturing wherever he could get a class to attend. And very successful Jukes seems to have been. Writing from Nottingham in June 1838 , he says, "I have had a very good class here, never less than two or three hundred, and frequently four or five hundred" (p, 26).

Having about 1838 made himself acquainted with practical surveying, he was in 1839 offered the appointment of Geological Surveyor of Newfoundland, a post he gladly accepted, and which occupied his time until the close of 1840. Into all the hardships of this work he entered with his accustomed good-will and spirits. Mr. Jukes contrasts his own easier lot with that of the hardy naturalist Prof. Stuiwitz, who "set off at the beginning of December in a boat with a little cuddy, to which (he says) my cabin is a palace, to see the winter fishing in Fortune Bay, with the chance of being frozen up on his return, and having to get ashore and come through the woods and snow," and he adds, "don't talk of my hardships and privations and courage" (p. 91). But the Newfoundland survey ended

* He matriculated at St. John's in 1830 , being then nineteen years of age. in October 1840 , and early in $1842 \mathrm{Mr}$. Jukes had the satisfaction to find himself appointed to the office of Naturalist to the Expedition for surveying Torres Straits, New Guinea, \&c., on board H.M. ship Fly, commanded by Captain E. P. Blackwood, R.N. This task, so congenial to him who loved no occupation so well as one requiring constant out-door exercise in the saddle, on foot, or on the water, occupied him until June, 1846 , and during his four years' absence his letters and journals furnish abundant materials of interest to the reader; much of which, however, will necessarily also be found in $\mathrm{Mr}$. Jukes's book entitled "Narrative of the Surveying Voyage of H.M.S. Fly (2 vols.), published in 1847 .

His description of scenery in the interior of Java is very interesting :- "Rich plains covered with all kinds of tropical productions, watered in every direction by clear rocky brooks, surrounded by mountains, either in single cones or serrated ranges, from 5,000 to 11,000 feet in height; abundance of game whenever we choose to stop and shoot, jungle-fowl, peacocks, deer, wild pigs, tigers. We crossed one great range of mountains by a path that led us through the extinct crater of a volcano, five miles across and 7,000 feet above the sea, and in the centre of which was a small cone and crater still in action, though when we looked down into it it was only blowing out steam, with a roar as of a thousand blast-furnaces. Take a scene on the slope of these mountains, as they dip into the plain of Malang. Scene :-An open mountain valley, full of coffee plantations, with small scattered villages, into which opens a deep mountain glen, cro ded with the rankest luxuriance of tropical vegetation, groups of tree feras and great broad-leaved plants, so as to arch over arid frequently hide altogether the full brook that comes flashing and roaring down the rocks in a succession of rapids, varied by waterfalls; the road, narrow, steep, and slippery, as it winds down the sides of the glen, expands into a broad green lane, with an exquisite carpet of turf as it opens on the more level lands" (pp. 238, 239).

Like every other man who is fond of the sea, we find him exclaiming, "I confess I am getting more and more enamoured of a sailor's life, and regret I did not know the navy early enough to enter it. I see it would have suited me exactly" (p. 25I).

But Mir. Jukes was destined to be a geologist. On the return of the good ship Fly, in June I846, he only allowed himself a few weeks at home before he had again "signed articles" to Sir H. T. de la Beche, then Director-General of the Geological Survey, and in October joined Profs. Ramsay and Forbes at Bala. These appear to have been his most intimate friends, as his letters to Ramsay abundantly attest. His letters to Forbes have, unfortunately, not been preserved. To those not connected with the Survey, this is the section of the book which it seems to us will be the least interesting, although here and there one comes upon a funny bit or a matter of public interest.

His fagging away at the geology of the rocks south of Conway forms the subject of many letters, and the solution of their puzzling structure is well given at p. 306. For

* For an account of his Newfoundland experiences and travels, sce also "Excursions in and about Newfoundland during the years 1839 and 1840 ," 2 vols. 8vo, London, 1842 . See also "Report on the Geology of Newfound. land," folio, 1840. 